\title{
ISOLASI FUKOSANTIN DARI RUMPUT LAUT COKLAT Padina australis DAN SITOTOKSISITASNYATERHADAP SEL MCF7 DAN SEL VERO
}

\section{Isolation of Fucoxanthin from Padina australis Brown Algae and Its Cytotoxicity against MCF7 and Vero cells}

\author{
Muhammad Nursid $^{1 *}$, Dedi Noviendri', Lestari Rahayu ${ }^{2}$ dan Virza Novelita ${ }^{2}$ \\ ${ }^{1}$ Pusat Penelitian dan Pengembangan Daya Saing Produk dan Bioteknologi Kelautan dan Perikanan, \\ JI. K.S.Tubun Petamburan VI, Jakarta Pusat, Indonesia \\ 2 Fakultas Farmasi Universitas Pancasila, Jakarta, Indonesia \\ * Korespondensi penulis: mnursid@kkp.go.id \\ Diterima: 1 Maret 2016 ; Disetujui: 15 Mei 2016
}

\begin{abstract}
ABSTRAK
Fukosantin merupakan karotenoid laut yang banyak terdapat pada rumput laut coklat. Fukosantin memiliki potensi yang menjanjikan untuk diaplikasikan pada bidang kesehatan. Padina australis merupakan salah satu rumput laut coklat yang banyak mengandung fukosantin. Penelitian ini bertujuan untuk mengisolasi fukosantin dari rumput laut $P$. australis dan mengetahui sitotoksisitasnya terhadap sel lestari kanker MCF7 dan sel normal Vero. Isolasi fukosantin dilakukan dengan menggunakan kromatografi kolom $\mathrm{SiO}_{2}$. Identifikasi fukosantin dilakukan dengan menggunakan liquid chromatography ion trap time of flight mass spectrofotometer (LC-IT-ToFMS) berdasarkan profil serapan UV dan berat molekul. Uji sitotoksik dilakukan dengan menggunakan uji (3-(4,5-dimethylthiazol-2-yl)-2,5-diphenyltetrazolium bromide) (uji MTT). Fukosantin berhasil diisolasi dari ekstrak kasar metanol. Fukosantin terkonfirmasi pada panjang gelombang maksimum ( $\lambda$ maks) $447 \mathrm{~nm}$ pada spektrum UV. Puncak monoisotopik ion molekul fukosantin terdeteksi pada nilai m/z 659,3612 [M+H]. Hasil uji MTT memperlihatkan bahwa fukosantin dari $P$. australis memiliki sitotoksisitas terhadap sel MCF7 dengan nilai $\mathrm{IC}_{50}$ sebesar $34,7 \mu \mathrm{g} / \mathrm{ml}$ dan relatif tidak toksik terhadap sel normal Vero dengan nilai $\mathrm{IC}_{50}$ sebesar $1071,6 \mu \mathrm{g} / \mathrm{ml}$.
\end{abstract}

KATAKUNCl: rumput laut coklat, Padina australis, fukosantin, sitotoksisitas

\begin{abstract}
Fucoxanthin is marine carotenoid that present in brown algae. It has considerable potential and promising application in human health. Padina australis is one of brown algae containing fucoxanthin. The aims of this research was to isolate fucoxanthin from $\underline{P}$. australis and to investigate cytotoxicity against MCF7 cancer cell and Vero normal cell line. Fucoxanthin isolation was performed by using $\mathrm{SiO}_{2}$ column chromatography. Fucoxanthin identification was done by using liquid chromatography ion trap time of flight mass spectrofotometer (LC-IT-ToF-MS) based on UV absorbance profile and molecular weight. Cytotoxicity test was evaluated by using MTT assay (3(4, 5-dimethylthiazol-2-yl)-2,5-diphenyltetrazolium bromide). Fucoxanthin was successfully isolated from methanolic extract. Fucoxanthin was confirmed on the maximum wave lenght ( $\lambda$ max) at $447 \mathrm{~nm}$ in the UV spectrum. Molecular ion monoisotopic peak of fucoxanthin was detected at $\mathrm{m} /$ z $659.3612[\mathrm{M}+\mathrm{H}]$. MTT test revealed that fucoxanthin from $\underline{\underline{P}}$ australis had cytotoxicity against MCF7 cell line with $I C_{50}$ value of $34.7 \mu \mathrm{g} / \mathrm{ml}$. The MTT test also showed that fucoxanthin relatively did not toxic to normal Vero cell line $\left(I C_{50}=1071.6 \mu \mathrm{g} / \mathrm{m} /\right)$.
\end{abstract}

KEYWORDS: brown algae, Padina australis, fucoxanthin, cytotoxicity

\section{PENDAHULUAN}

Fukosantin merupakan salah satu pigmen yang dominan dari golongan karotenoid yang terdapat dalam lingkungan laut. Pigmen ini terutama dihasilkan oleh rumput laut coklat (Phaeophyta) (Peng, Yuan,
Wu, \& Wang, 2011; Terasaki et al., 2009) sekaligus menjadi faktor utama yang menentukan warna coklat pada rumput laut tersebut. Ikatan allenic dengan gugus fungsi epoksi, hidroksi, dan kabonil menjadi ciri utama dari fukosantin (D'Orazio et al., 2012). Fukosantin memiliki potensi yang besar untuk 
dikembangkan baik sebagai bahan obat antikanker maupun sebagai pangan fungsional karena memiliki khasiat sebagai antikanker, antioksidan, antiobesitas dan antidiabetes (Lin et al., 2016).

Penyakit kanker yang paling sering terjadi pada wanita adalah kanker payudara diikuti oleh kanker serviks (Holleczek, Jensen, \& Brenner, 2013; Parkin, Bray, Ferlay, \& Pisani, 2005). Upaya untuk mengobati dan mencegah kanker payudara masih terus dilakukan. Fukosantin menjadi salah satu bahan alami laut yang memiliki prospek untuk dikembangkan sebagai bahan antikanker. Beberapa penelitian dan review efek antikanker fukosantin misalnya dilakukan oleh Kumar, Hosokawa dan Miyashita (2013), Martin (2015), Nara, Terasaki dan Nagao (2005), dan Sugawara, Matsubara, Akagi, Mori dan Hirata (2006).

Indonesia memiliki garis pantai yang panjang sebagai habitat yang baik untuk pertumbuhan dan perkembangan rumput laut coklat. Salah satu rumput laut coklat yang potensial sebagai sumber fukosantin adalah Padina australis Hasil penelitian kami memperlihatkan bahwa rumput laut $P$. australis yang diambil dari Pantai Binuangeun, Banten, memiliki kadar fukosantin yang cukup tinggi (Nursid, Wikanta, \& Susilowati, 2013). Sementara itu Limantara dan Heriyanto (2011) melaporkan bahwa metanol merupakan pelarut yang terbaik untuk mengekstrak fukosantin dari sampel $P$. australis yang diambil dari Sumenep Madura, Jawa Timur. Kandungan fukosantin yang tinggi juga terdapat pada $P$. australis yang diambil dari perairan Port Dickson, Negeri Sembilan Malaysia (Jaswir, Noviendri, Salleh, Taher, \& Miyashita, 2011). Kandungan fukosantin dari rumput laut coklat Sargassum duplicatum dari perairan yang sama sebesar $1,01 \mathrm{mg} / \mathrm{g}$ berat kering (Noviendri et al., 2011). Hasil studi Husni, Putra dan Lelana, (2014) memperlihatkan bahwa $P$. australis dari Pantai Drini, Gunung Kidul Yogyakarta memiliki aktivitas antioksidan yang cukup baik. Sampai saat ini, laporan tentang isolasi fukosantin dan khasiatnya sebagai antikanker dari rumput laut $P$. australis asal Perairan Indonesia masih terbatas. Dengan mempertimbangkan keberadaan $P$. australis yang melimpah di Indonesia, maka eksplorasi kandungan fukosantin $P$. australis dan bioaktivitasnya sebagai antikanker menjadi penting untuk dilakukan.

Penelitian ini bertujuan untuk mengisolasi fukosantin dari rumput laut $P$. australis dan mengetahui efek sitotoksiknya terhadap sel kanker payudara MCF7 dan sel normal Vero.

\section{BAHAN DAN METODE}

\section{Ekstraksi dan Isolasi Fukosantin}

Sampel rumput laut $P$. australis diambil dari pantai Indrayanti Yogyakarta pada tahun 2014 lalu disimpan dalam keadaaan beku pada suhu $-20^{\circ} \mathrm{C}$. Isolasi fukosantin dilakukan menurut metode Jaswir et al. (2011) dan Noviendri et al. (2011) dengan beberapa modifikasi. Sebanyak $1 \mathrm{~kg}$ sampel dicuci dengan air tawar lalu dikeringbekukan dengan freeze drier. Pengeringan dengan freeze drier ini bertujuan untuk mengeliminasi kandungan air sehingga memudahkan proses evaporasi. Rumput laut kering selanjutnya di maserasi menggunakan aseton : metanol dengan perbandingan $7: 3(\mathrm{v} / \mathrm{v})$ selama 24 jam kemudian disaring. Proses maserasi dilakukan sebanyak 3 kali. Filtrat yang diperoleh dievaporasi dengan rotavapor vakum hingga diperoleh ekstrak kental. Ekstrak kental selanjutnya dipartisi dalam corong pisah dengan menggunakan metanol-air : $n$-heksana dengan perbandingan $1: 1$. Fraksi metanol yang diperoleh dievaporasi dengan rotavapor vakum. Sisa pelarut yang terdapat dalam ekstrak kental dikeringkan dengan bantuan gas nitrogen. Dari tahapan ini diperoleh fraksi metanol-air yang mengandung fukosantin dan senyawa-senyawa polar terutama golongan fenol. Selanjutnya isolasi fukosantin dilakukan dengan kromatografi kolom $\mathrm{SiO}_{2}$. Pelarut yang digunakan sebagai eluen adalah n-heksana $100 \%$ lalu dilanjutkan secara isokratik dengan $\mathrm{n}$-heksana : aseton dengan perbandingan 6:4 (v/v) secara berulang sampai fukosantin terelusi. Fraksi fukosantin dapat ditandai dari warna oranye. Fukosantin yang diperoleh lalu dikeringkan dengan menguapkan pelarutnya menggunakan rotavapor vakum. Semua proses isolasi fukosantin tersebut dilakukan di dalam ruang gelap.

\section{Identifikasi Fukosantin}

Fukosantin diidentifikasi berdasarkan serapan UV $\left(\lambda_{\max }\right)$ dan berat molekul yang dinyatakan sebagai $\mathrm{m} / \mathrm{z}$. Profil serapan UV dan nilai $\mathrm{m} / \mathrm{z}$ diperoleh dengan instrumen Liquid Chromatography lon Trap Time of Flight Mass Spectrofotometer (LC-IT-ToF-MS). Sebanyak $1 \mathrm{mg}$ sampel dilarutkan dalam metanol HPLC grade dan dihomogenkan, lalu disaring dengan membran filter 0,4 $\mu \mathrm{m}$. Sampel yang dinjeksikan ke dalam alat sebanyak $10 \mu \mathrm{l}$. Alat yang digunakan adalah instrumen Shimadzu LC-10AD yang dilengkapi dengan photo diode array (PDA) detector, kolom Shim-Pack VP-ODS $\mathrm{C}_{18} 2 \times 150 \mathrm{~mm}$ dengan fase gerak air-asetonitril secara gradien selama 40 menit dan laju alir 0,2 $\mathrm{ml} / \mathrm{menit}$.

\section{Uji Sitotoksisitas}

Uji sitotoksisitas dilakukan dengan menggunakan sel kanker payudara MCF7 (Michigan Cancer Foundation-7) dan sel normal Vero. Sel MCF7 diperoleh dari Pusat Studi Satwa Primata Institut Pertanian Bogor sedangkan sel Vero diperoleh dari Laboratorium Parasitologi Fakultas Kedokteran 
Universitas Gadjah Mada, Yogyakarta. Uji dilakukan dengan metode MTT (3-(4,5-dimethylthiazol-2-yl)-2,5diphenyltetrazolium bromide) menurut Zachary (2003) dengan beberapa modifikasi. Sel MCF7 dipelihara dalam media Roswell Park Memorial Institute (RPMI) sedangkan sel Vero dibiakkan dalam media M199. Kedua jenis media tersebut dilengkapi dengan fetal bovine serum (FBS) 10\%, penisilin-streptomisin $2 \%$ dan fungison $0,5 \%$. Sel diinkubasi dalam inkubator $\mathrm{CO}_{2}$ pada suhu $37^{\circ} \mathrm{C}$ dengan aliran $\mathrm{CO}_{2} 5 \mathrm{ml} /$ menit. Secara ringkas metode uji yang dilakukan mengacu pada Ebada, Edrada, Lin, dan Proksch (2008) dengan beberapa modifikasi. Sebanyak $1 \times 10^{4} \mathrm{sel} / \mathrm{sumur}$ ditumbuhkan dalam mikroplat dan diinkubasi selama 12 jam dalam inkubator $\mathrm{CO}_{2}$. Selanjutnya sebanyak $100 \mu \mathrm{l}$ larutan uji dengan konsentrasi 10, 20, 40, 80 dan $160 \mu \mathrm{g} / \mathrm{ml}$ dimasukkan ke dalam mikroplat yang sudah berisi sel dan diinkubasi selama 24 jam pada suhu $37^{\circ} \mathrm{C}$ dalam inkubator $\mathrm{CO}_{2}$. Morfologi sel setelah terpapar ekstrak selama 24 jam didokumentasikan, lalu ke dalam mikroplat ditambahkan larutan MTT dengan konsentrasi $0,5 \mathrm{mg} / \mathrm{ml}$. Reaksi antara MTT dengan sel dilakukan selama 4 jam di dalam inkubator $\mathrm{CO}_{2}$. Reaksi MTT dihentikan dengan penambahan $100 \mu$ l Sodium Dodesil Sulfat (SDS) 10\%. Setelah 12 jam waktu inkubasi, absorbansi tiap sumur dibaca dengan microplate reader pada panjang gelombang $570 \mathrm{~nm}$. Data absorbansi setiap sumuran digunakan untuk menghitung mortalitas sel (\%). Analisis probit dengan bantuan program Minitab 16,0 dilakukan untuk mendapatkan nilai $\mathrm{IC}_{50}$.

\section{HASIL DAN BAHASAN}

\section{Ekstraksi dan Isolasi Fukosantin}

Proses maserasi menggunakan campuran aseton dan metanol dengan perbandingan $7: 3$ seperti yang dilakukan oleh Jaswir et al. (2011) dan Noviendri et al.(2011). Aseton bersifat semipolar sedangkan metanol merupakan pelarut yang polar. Gabungan kedua pelarut tersebut diharapkan dapat mengekstraksi secara optimal pigmen-pigmen karotenoid yang terdapat dalam sampel rumput laut. Penggunaan metanol juga membantu mengoptimalkan proses ekstraksi karotenoid fukosantin karena pigmen ini tergolong polar dengan adanya gugus $\mathrm{OH}$. Torres et al. (2014) menyatakan bahwa metanol merupakan pelarut yang paling baik dalam mengekstraksi total karotenoid pada rumput laut diikuti oleh DMSO dan aseton. Limantara dan Heriyanto (2011) menyatakan bahwa di antara pelarut metanol, etanol, asetonitril, DMSO dan aseton, metanol merupakan pelarut yang paling baik untuk mengekstraksi fukosantin. Hasil penelitian lain memperlihatkan juga bahwa metanol merupakan pelarut yang paling baik untuk mengesktraksi fukosantin dari rumput laut coklat Laminalia japonica (Kanazawa et al., 2008). Dalam penelitian ini, rendemen ekstrak kasar yang dihasilkan sebesar $6,2 \mathrm{~g} / \mathrm{kg}$ rumput laut basah $(0,62 \%)$. Secara garis besar, proses fraksinasi dan isolasi untuk mendapatkan fukosantin dalam penelitian ini dilakukan menurut metode Jaswir et al. Fraksinasi tahap awal terhadap estrak kasar dengan menggunakan campuran metanol-air (aqueous suspension) dan nheksana menghasilkan dua fase yang memisah dengan baik setelah dibiarkan selama 1 malam. Fase pertama (bagian atas) merupakan fraksi n-heksana yang mengandung senyawa-senyawa non polar seperti asam-asam lemak dan klorofil sedangkan fase kedua (bagian bawah) merupakan fraksi metanol-air yang mengandung senyawa polar seperti pigmen santofil, termasuk fukosantin dan senyawa-senyawa polifenol.

Dalam penelitian ini, fukosantin berhasil diisolasi dari fraksi metanol-air dengan kolom $\mathrm{SiO}_{2}$. Fraksi yang mengandung senyawa mayor fukosantin terelusi dengan pelarut $n$-heksana : aseton (6:4) v/v. Fukosantin berwarna oranye terlihat dengan jelas pada matriks kolom ketika proses elusi sedang berlangsung. Senyawa-senyawa yang kurang polar (karotenoid non fukosantin dan klorofil) dalam fraksi ini sudah terelusi terlebih dahulu dengan pelarut $n$-heksana $100 \%$. Pada saat elusi dilakukan dengan $n$-heksana : aseton (6:4) v/v perlahan-lahan fukosantin mulai terelusi dan memisah dengan senyawa-senyawa polar yang kemungkinan besar merupakan senyawa-senyawa polifenol.

Untuk mengkonfirmasi bahwa senyawa tersebut merupakan fukosantin dilakukan analisis menggunakan high performance liquid chromatography (HPLC), ultraviolet (UV) dan mass spectra (MS). Puncak fukosantin terelusi pada menit ke-20,5 dalam sistem HPLC (Gambar 1A). Puncak tersebut memiliki serapan UV maksimum pada panjang gelombang $447 \mathrm{~nm}$ (Gambar 1B). Serapan maksimum $447 \mathrm{~nm}$ merupakan salah satu sidik jari senyawa fukosantin. Spektrum LC-IT-ToF-MS mode positif memperlihatkan adanya puncak monoisotopik ion molekul pada m/z 681,3247 [M+Na] dan 659,3612 $[\mathrm{M}+\mathrm{H}]($ Gambar $1 \mathrm{C})$. Data $\mathrm{m} / \mathrm{z}$ tersebut sesuai dengan puncak monoisotopik molekul fukosantin yang memiliki berat molekul $658,92 \mathrm{~g} / \mathrm{mol}$. Munculnya puncak ion molekul pada m/z 641,3756 menunjukkan spektra fukosantin yang kehilangan 2 atom $\mathrm{H}$ dan 1 atom O.

Separasi fukosantin dari fase metanol-air dengan menggunakan fase diam silika gel dan fase gerak $n$ heksana-aseton dengan perbandingan $6: 4$ sukses untuk memisahkan fukosantin dengan senyawa- 
senyawa lain seperti sisa-sisa klorofil a, klorofil b, $\beta$ karoten, dan polifenol. Campuran kedua pelarut tersebut dipilih dalam penelitian ini berdasarkan Noviendri et al. (2011) dan Xia et al. (2013). Berturutturut kedua peneliti tersebut berhasil mengisolasi fukosantin dari rumput laut $P$.australis dari perairan Malaysia dan fukosantin dari diatom Odontella aurita.

Aktivitas antikanker dari fukosantin dihubungkan dengan karakteristik struktur kimianya yang unik. Mayoritas fukosantin pada rumput laut coklat terdapat dalam bentuk all-trans fukosantin, selebihnya terdapat dalam cis-fukosantin. Dalam kromatogram HPLC (Gambar 1A), puncak yang paling tinggi merupakan puncak dari trans-fukosantin sedangkan puncak tertinggi kedua merupakan cis-fukosantin. Menurut Nakazawa, Sashima, Hosokawa dan Miyashita, (2009), isomer dalam bentuk cis-fukosantin cenderung kurang stabil dibanding dalam bentuk trans-fukosantin. Hal ini yang menyebabkan sebagian besar karotenoid berada dalam bentuk trans. Efek antiproliferasi

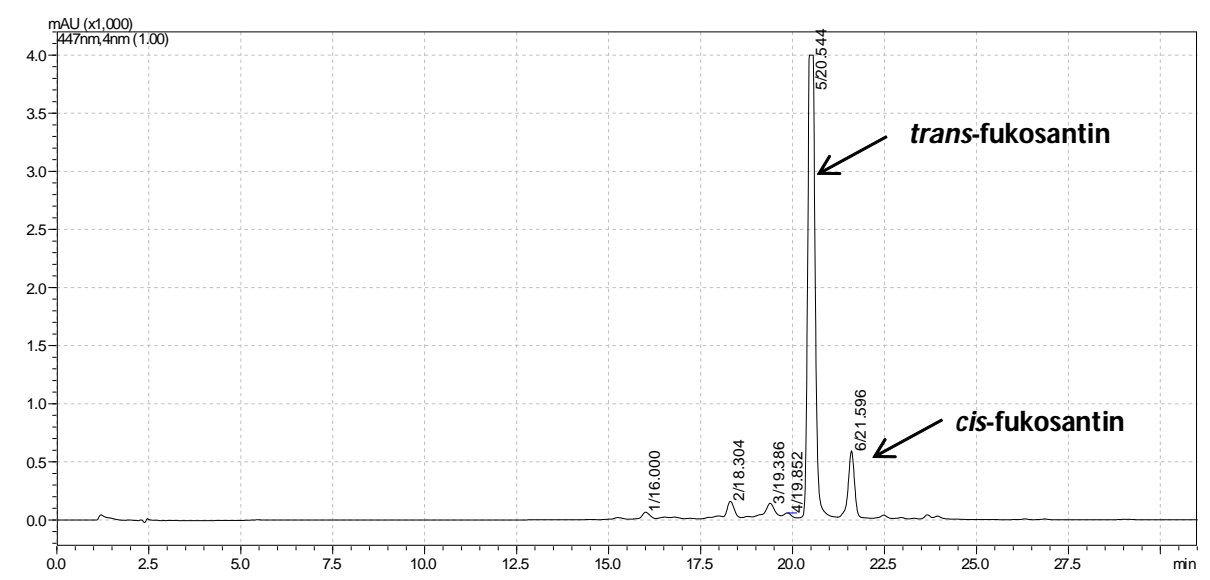

A

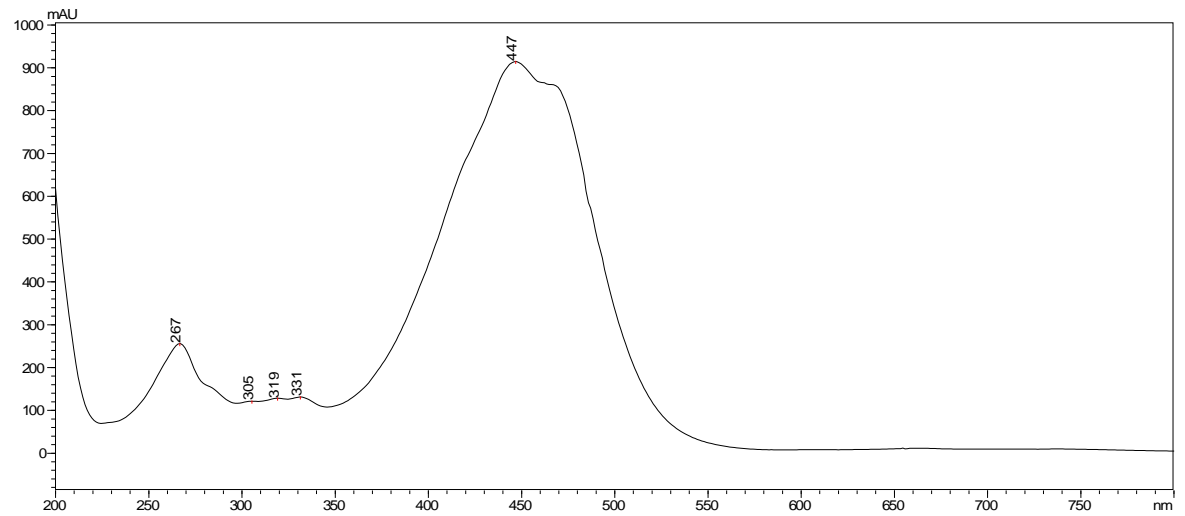

B

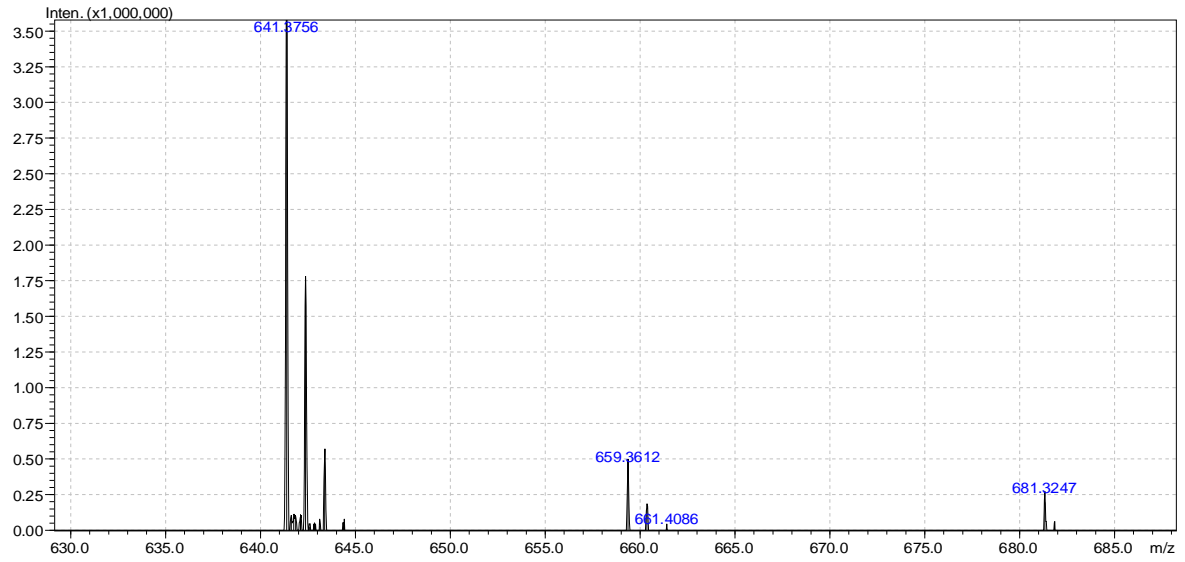

C

Gambar 1. Kromatogram HPLC (A), serapan UV (B), dan puncak ion fukosantin (C) Figure 1. HPLC chromatogram (A), UV absorbance (B), and fucoxanthin ion peak (C) 
Tabel 1. Hasil uji sitotoksik fukosantin terhadap sel MCF7 dan sel Vero

Table 1. Result of fucoxanthin cytotoxicity test against MCF7 and Vero cells

\begin{tabular}{ccccc}
\hline $\begin{array}{c}\text { Dosis/doses } \\
(\boldsymbol{\mu g} / \mathbf{m l})\end{array}$ & \multicolumn{2}{c}{ Sel MCF7/MCF7 Cell } & \multicolumn{2}{c}{ Sel Vero/Vero Cell } \\
\hline 10 & Mortalitas/mortality $(\%)$ & $\mathbf{I C}_{50}(\boldsymbol{\mu g} / \mathbf{m l})$ & Mortalitas/mortality $(\%)$ & IC $_{50}(\boldsymbol{\mu g} / \mathbf{m l})$ \\
\hline 20 & $18.3 \pm 17.2$ & & $6.4 \pm 3.5$ & \\
40 & $9.4 \pm 2.2$ & & $9.4 \pm 5.6$ & \\
80 & $53.7 \pm 6.2$ & 34.3 & $19.4 \pm 0.5$ & 1071.6 \\
160 & $87.7 \pm 13.2$ & & $16.5 \pm 12.3$ & \\
\hline
\end{tabular}

fukosantin salah satunya tergantung pada struktur isomer cis atau trans. cis-fukosantin memiliki aktivitas antiproliferasi yang lebih tinggi dibanding transfukosantin, hal ini disebabkan isomer dalam bentuk cis-fukosantin memiliki bentuk yang disebut dengan steric hindrance.

\section{Uji Sitotoksisitas}

Hasil uji sitotoksisitas fukosantin terhadap sel MCF7 memperlihatkan bahwa pada dosis $40 \mu \mathrm{g} / \mathrm{ml}$ jumlah sel MCF7 yang mati mencapai 53,7\% (Tabel 1), sebaliknya pada dosis yang sama, sel Vero yang mengalami kematian hanya mencapai 19,4\%. Hasil analisis probit memperlihatkan bahwa nilai $\mathrm{IC}_{50}$ fukosantin terhadap sel MCF7 sebesar $34,3 \mu \mathrm{g} / \mathrm{ml}$ yang setara dengan $0,052 \mathrm{mM}$, sedangkan nilai $I_{50}$ fukosantin terhadap sel Vero sebesar $1,62 \mathrm{mM}$. Nilai $\mathrm{IC}_{50}$ fukosantin terhadap sel MCF7 yang sebesar 34,3 $\mu \mathrm{g} / \mathrm{ml}$ masih jauh lebih kecil dari nilai $\mathrm{IC}_{50}$ fukosantin terhadap sel Vero. Hal ini menunjukkan bahwa pada dosis IC ${ }_{50}$ fukosantin terhadap sel MCF7 (0,052 mM), sel Vero masih menunjukkan viabilitas yang tinggi. Nilai $I_{50}$ fukosantin yang diperoleh ini masih lebih baik dari nilai $I_{50}$ fukosantin dari P.australis terhadap sel H1299 asal perairan Port Dickson, Negeri Sembilan Malaysia yakni sebesar 1,63 mM terhadap sel H1299 (Jaswir et al., 2011). Hal ini kemungkinan besar berhubungan dengan perbedaan respon sel yang berbeda antara sel MCF7 yang digunakan dalam penelitian ini dengan sel $\mathrm{H} 1299$.

Hasil uji sitotoksik tersebut juga dikonfirmasi dengan kenampakan morfologi sel MCF7 dan Vero setelah diberi fukosantin selama 24 jam pada berbagai dosis. Sebagai contoh, pada dosis $40 \mu \mathrm{g} / \mathrm{ml}$ morfologi sel MCF7 berbeda bentuk dan kepadatannya dibandingkan dengan sel MCF7 tanpa perlakuan (kontrol sel) (Gambar 2). Kristal formazan yang terbentuk jumlahnya terlihat lebih sedikit dibanding dengan jumlah kristal formazan pada kontrol sel. Jumlah kristal formazan tersebut sebanding dengan populasi sel yang hidup. Sebaliknya, pada sel Vero, perbedaan morfologi sel pada dosis fukosantin $40 \mu \mathrm{g} /$
Sel MCF7
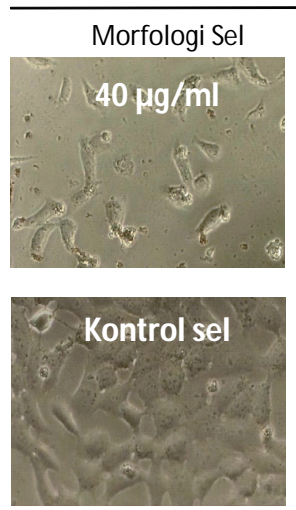

Kristal Formazan
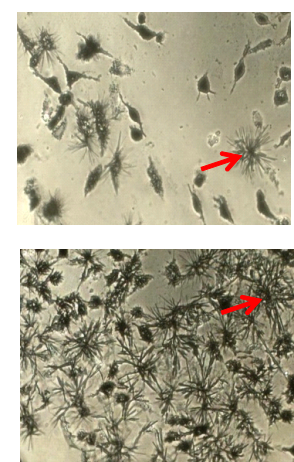

Sel Vero
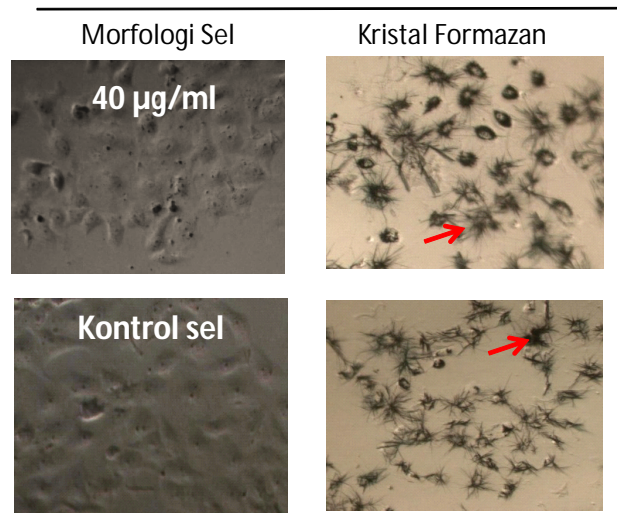

Keterangan/Note: Kristal formazan ditunjukkan dengan panah merah/ Formazan crystal was pointed with red arrow

Gambar 2. Morfologi sel MCF7 dan Vero setelah diberi perlakuan fukosantin selama 24 jam. Figure 2. Morphology of MCF7 and Vero cells after being treated with fucoxanthin for 24 hours. 
$\mathrm{mL}$ dengan kontrol sel tidak jauh berbeda, demikian juga halnya dengan jumlah kristal formazan yang terbentuk. Hal ini menunjukkan bahwa fukosantin pada dosis $40 \mu \mathrm{g} / \mathrm{mL}$ belum menunjukkan efek sitotoksik yang berarti terhadap sel Vero. Efek sitotoksik fukosantin dari $P$. australis terhadap sel Vero, sejauh yang diketahui penulis belum pernah dilaporkan sebelumnya.

Aktivitas antikanker melalui induksi apoptosis dari fukosantin terhadap sel MCF7 sensitif estrogen ditunjukkan oleh Rwigemera, Mamelona dan Martin (2014). Efek antiproliferasi fukosantin terhadap sel SKHep-1 (human liver adenocarcinoma) telah dilaporkan oleh Liu, Huang, Hosokawa,Miyashita dan Hu, (2009). Dinyatakan bahwa terdapat korelasi yang kuat antara konsentrasi fukosantin dengan efek anti proliferasinya. Mekanisme penghambatan fukosantin terhadap proliferasi sel kanker terjadi melalui induksi apoptosis dan penghambatan siklus sel yang bermuara pada represi metastasis (Kumar et al., 2013). Induksi apoptosis fukosantin pada sel leukemia $\mathrm{HL}-60$ terjadi melalui represi level protein $\mathrm{Bcl}-2$ (sebuah protein penekan apoptosis) yang terlibat dalam down regulation pada jalur apoptosis sehingga menyebabkan berkurangnya viabilitas sel leukemia tersebut (Nakazawa et al., 2009). Pada sel PC-3 (human prostate cancer) fukosantin menginduksi apoptosis melalui aktivasi caspase-3 (Kotake-Nara, Asai, \& Nagao, 2005). Fukosantin menghambat proliferasi sel WiDr melalui mekanisme penghambatan siklus sel pada fase $G_{0} / G_{1}$. Penghambatan siklus sel ini terjadi melalui upregulation protein p21WAF1/Cip1 (Das et al., 2005). Fukosantin juga memperlihatkan kemampuan perlindungan dalam melawan kerusakan DNA dari radiasi UV-B pada sel fibroblas manusia (Heo \& Jeon, 2009). Hal ini menunjukkan bahwa fukosantin juga memiliki kemampuan dalam mencegah terjadinya kanker (efek preventif). Efek antiproliferasi fukosantin terhadap sel kanker juga terjadi melalui mekanisme antiangiogenesis. Dalam hal ini fukosantin dapat menekan pembentukan pembuluh darah baru pada sel endotel dan sel cincin aorta pada tikus (Sugawara et al., 2006). Martin (2015) menyebutkan bahwa mekanisme antiproliferasi fukosantin terhadap sel kanker dapat diringkas melalui induksi apoptosis, penghambatan siklus sel dan anti angiogenesis.

Meskipun fukosantin memiliki spektrum yang luas dalam menghambat proliferasi sel kanker tetapi studi menunjukkan bahwa fukosantin tidak bersifat sitotoksik terhadap sel normal (Kumar et al., 2013). Hal ini sesuai dengan hasil eksperimen yang diperoleh dalam penelitian ini yang mendapatkan nilai $I_{50}$ fukosantin $P$. australis sebesar $1071,6 \mu \mathrm{g} / \mathrm{mL}$ terhadap sel normal Vero. Sel Vero merupakan salah satu sel normal yang banyak digunakan dalam penelitian biologi sel. Sel ini pertama kali diisolasi dari ginjal normal monyet hijau Afrika pada tahun 1962 oleh Yasumura dan Kawakita di Universitas Chiba, Jepang (ATCC, 2016a). Nilai IC ${ }_{50}$ fukosantin terhadap sel Vero sekitar 30 kali lipat dari nilai $\mathrm{IC}_{50}$ fukosantin P.australis terhadap sel MCF7 yang sebesar $34,3 \mu \mathrm{g} / \mathrm{ml}$. Hasil penelitian Liu et al. (2009), tidak berbeda jauh dengan hasil penelitian ini. Dikatakan bahwa fukosantin relatif tidak menghambat pertumbuhan sel BNL CL.2 (murine embryonic hepatic) yang diberi perlakuan selama 24 dan 48 jam. Sel BNL CL.2 merupakan sel normal yang diisolasi dari liver tikus Mus musculus (ATCC, 2016b). Secara in vivo, fukosantin yang diberikan secara oral selama 28 hari juga tidak menunjukkan gejala toksik pada tikus (Kadekaru, Toyama \& Yasumoto, 2008). Pemberian fukosantin secara oral pada dosis 500 dan $1000 \mathrm{mg} / \mathrm{kg}$ bb tidak menyebabkan toksisitas dan abnormalitas ginjal dan hati pada mencit (Beppu, Niwano, Tsukui, Hosokawa, \& Miyashita, 2009). Dengan sifat antikankernya yang cukup baik dan rendahnya toksisitas fukosantin terhadap sel normal, serta melimpahnya bahan baku P.australis di Indonesia, maka fukosantin memiliki prospek yang baik untuk dikembangkan sebagai agen terapi antikanker khususnya kanker payudara.

Fukosantin memiliki aktivitas biologis yang menonjol disebabkan oleh struktur molekulnya yang unik mirip dengan neoxanthin, dinoxanthin, dan peridinin yang berbeda dengan karotenoid lain seperti $\beta$-carotene dan astaxanthin. Keunikan struktur tersebut dicirikan dengan adanya gugus fungsional epoksi, hidroksi, karboksil dan karboksil moety (Peng et al., 2011). Ikatan alenik pada fukosantin bertanggung jawab terhadap aktivitas antioksidannya (Sachindra et al., 2007) sedangkan efek antiproliferasi fukosantin kemungkinan besar disebabkan oleh adanya struktur 5,6-epoksi pada fukosantin (Asai, Sugawara, Ono \& Nagao, 2004). Afolayan, Bolton, Lategan, Smith \& Beukes (2008) juga menduga ada hubungan antara ikatan alenik dengan sifat antiplasmodial pada fukosantin. Hasil analisis secara in silico memperlihatkan bahwa gugus karboksil pada fukosantin membentuk ikatan hidrogen dengan tubulin pada sel yang berakibat pada depolimerasasi mikrotubulin dan penghambatan siklus sel (Januar, Dewi,Marraskuranto \& Wikanta, 2012).

\section{KESIMPULAN}

Fukosantin dari rumput laut coklat P.australis terelusi pada menit ke 20,5 pada sistem HPLC. Puncak tersebut terkonfirmasi sebagai fukosantin karena memiliki serapan UV maksimum pada panjang 
gelombang $447 \mathrm{~nm}$ dan terdeteksinya puncak monoisotopik ion molekul fukosantin pada nilai $\mathrm{m} / \mathrm{z}$ $659,3612[\mathrm{M}+\mathrm{H}]$ (berat molekul fukosantin 658,92 g/ mol). Fukosantin dari $P$. australis bersifat sitotoksik terhadap sel MCF7 dengan nilai $I_{50}$ sebesar $34,7 \mu \mathrm{g} /$ dan relatif tidak toksik terhadap sel normal Vero dengan nilai $I C_{50}$ sebesar $1071,6 \mu \mathrm{g} / \mathrm{ml}$.

\section{UCAPAN TERIMA KASIH}

Penelitian ini didanai oleh APBN tahun 2015 pada Balai Besar Litbang Pengolahan Produk dan Bioteknologi Kelautan dan Perikanan. Penulis mengucapkan terima kasih kepada Nurrahmi Dewi Fajarningsih, M.Biotech (Adv) atas spesimen rumput laut $P$.australis yang digunakan dalam penelitian ini. Penulis juga mengucapkan terima kasih kepada Sri Iswani, S.Si atas bantuannya dalam analisis LC-ITToF-MS.

\section{DAFTAR PUSTAKA}

Afolayan, A. F., Bolton, J. J., Lategan, C. A., Smith, P. J., \& Beukes, D. R. (2008). Fucoxanthin, tetraprenylated toluquinone and toluhydroquinone metabolites from Sargassum heterophyllum inhibit the in vitro growth of the malaria parasite Plasmodium falciparum. $Z$. Naturforsch C, 63(11-12), 848-52.

American Type Cell Culture (ATCC). (2016a). Vero (ATCC CCL-81. http://www.atcc.org/products/all/CCL81.aspx\#characteristics. Diakses 11 April 2016.

American Type Cell Culture (ATCC). (2016b). BNL CL.2 (ATCC TIB-73. http://www.atcc.org/products/all/TIB73.aspx. Diakses tanggal 7 April 2016.

Asai, A., Sugawara, T., Ono, H., \& Nagao, A. (2004). Biotransformation of fucoxanthinol into amarouciaxanthin $A$ in mice and HepG2 cells: formation and cytotoxicity of fucoxanthin metabolites. Drug. Metab. Dispos, 32, 205-211.

Beppu, F., Niwano, Y., Tsukui, T., Hosokawa, M., \& Miyashita, K. (2009). Single and repeated oral dose toxicity study of fucoxanthin (FX), a marine carotenoid, in mice. J. Toxicol. Sci, 34, 501-510.

Das, S. K., Hashimoto, T., Shimizu, K., Yoshida, T., Sakai, T., Sowa, Y., Komoto, A., \& Kanazawa, K. (2005). Fucoxanthin induces cell cycle arrest at G0/G1 phase in human colon carcinoma cells through upregulation of p21WAF1/Cip1. Biochim. Biophys. Acta, 1726 (3), 328-35.

D'Orazio, N., Gemello, E., Gammone, M. A., Girolamo, M., Ficoneri, C., \& Riccioni, G. (2012). Fucoxanthin: A Treasure from the Sea. Mar. Drugs, 10, $604-616$.

Ebada, E. S., Edrada, R. U., Lin, W., \& Proksch, P. (2008). Methods for isolation, purification and structural elucidation of bioactive secondary metabolites from marine invertebrates. Nat. Prot, 3(12), 1820-1831.

Heo, S. J \& Jeon Y. J. (2009). Protective effect of fucoxanthin isolated from Sargassum siliquastrum on UV-B induced cell damage. J. Photochem. Photobiol, 95(2),101-107.

Holleczek, B., Jensen, L., \& Brenner, H. (2013). Breast Cancer Survival in Germany: A Population-Based High Resolution Study from Saarland. PLOS ONE, 8(7), e70680.

Husni, A., Putra, D. R., \& Lelana, Y.B. (2014). Aktivitas antioksidan Padina sp. pada berbagai suhu dan lama pengeringan. JPB Kelautan dan Perikanan, 9(2), 165 $-173$

Januar, H. I., Dewi, A. S., Marraskuranto, E \& Wikanta, T. (2012). In silico study of fucoxanthin as a tumor cytotoxic agent. J. Pharm. Biollied Sci, 4(1), 56 - 59.

Jaswir, I., Noviendi, D., Salleh, H. M., Taher, M., \& Miyashita, K. (2011). Isolation of fucoxanthin and fatty acids analysis of Padina australis and cytotoxic effect of fucoxanthin on human lung cancer (H1299) cell lines. Afr. J. Biotechnol, 10(81), 18855-18862.

Kanazawa, K., Ozaki, Y., Hashimoto, T., Das, S.K., Matsushita, S., Hirano, M., Okada, T., Komoto, A., Mori, N., \& Nakatsuka, M. (2008). Commercial scale preparation of biofunctional fucoxanthin from waste parts of brown sea algae Laminalia japonica. Food Sci. Technol. Res, 14(6), 573- 582.

Kadekaru, T., Toyama, H., \& Yasumoto, T. (2008). Safety evaluation of fucoxanthin purified from Undaria pinnatifida. J. Jpn. Soc. Food Sci., 55, 304-308.

Kotake-Nara, Asai, A., \& Nagao, A. (2005). Neoxanthin and fucoxanthin induce apoptosis in PC-3 human prostate cancer cells. Cancer Let, 220(1): 75 - 84.

Kumar, S. R., Hosokawa, M., \& Miyashita, K. (2013). Fucoxanthin: A Marine Carotenoid Exerting Anti-Cancer Effects by Affecting Multiple Mechanisms. Mar. Drugs, 11, 5130-5147.

Limantara, L \& Heriyanto. (2011). Optimasi proses ekstraksi fukosantin rumput laut coklat Padina australis Hauck menggunakan pelarut organik polar. IImu Kelautan, 16(2), 86 - 94.

Liu, C. L., Huang, Y. S., Hosokawa, M., Miyashita, K., \& $\mathrm{Hu}, \mathrm{M}$. L. (2009). Inhibition of proliferation of a hepatoma cell line by fucoxanthin in relation to cell cycle arrest and enhanced gap junctional intercellular communication. Chem. Biol. Interact, 182(2-3), 165 $-172$.

Lin, J., Huang, L., Yu, J., Xiang, S., Wang, J., Zhang, Z., Yan, X., Cui, W., He, S., \& Wang, Q. (2016). Fucoxanthin, a marine carotenoid, reverses scopolamine-induced cognitive impairments in mice and inhibits acetylcholinesterase in vitro. Mar. Drugs, 14(67) , 1 17.

Martin, L. J. (2015). Fucoxanthin and its metabolite fucoxanthinol in cancer prevention and treatment. Mar. Drugs, 13, 4784-4798.

Nakazawa, Y., Sashima, T., Hosokawa, M., \& Miyashita, K. (2009). Comparative evaluation of growth inhibitory effect of stereo isomers of fucoxanthin in human cancer cell lines. J. of Func. Foods, 1(1): 88-97.

Nara, K. E., Terasaki, M., \& Nagao, A. (2005). Characterization of apoptosis induced by fucoxanthin 
in human promyelocytic leukemia cells. Biosci. Biotechnol. Biochem, 69, 224-227.

Noviendri, D., Jaswir, I., Salleh, H. M., Taher, M., Miyashita, K., \& Ramli, K. (2011). Fucoxanthin extraction and fatty acid analysis of Sargassum binderi and $S$. duplicatum. Journal of Medicinal Plants Research, 5(11), 2405-2412.

Nursid, M., Wikanta, T., \& Susilowati, R. (2013). Aktivitas antioksidan, sitotoksisitas dan kandungan fukosantin ekstrak rumput laut coklat dari Pantai Binuangeun, Banten. JPB Kelautan dan Perikanan, $8(1), 73$ - 84.

Parkin, D. M., Bray, F., Ferlay, J., \& Pisani, P. (2005). Global cancer statistics, 2002. CA Cancer J. Clin, 55,74108.

Peng, J., Yuan, J. P., Wu, C. F., \& Wang, J. H. (2011) Fucoxanthin, a marine carotenoid present in brown seaweeds and diatoms: metabolism and bioactivities relevant to human health. Mar. Drugs, 9, 1806-1828

Rwigemera, A., Mamelona, J., \& Martin, L. J. (2014). Inhibitory effects of fucoxanthinol on the viability of human breast cancer cell lines MCF-7 and MDA-MB231 are correlated with modulation of the NF-kappa B pathway. Cell Biol. Toxicol, 30(3),157-67

Sachindra, N. M., Sato, E., Maeda, H., Hosokawa, M., Niwano, Y., Kohno, Y., \& Miyashita, K. (2007). Radical scavenging and singlet oxygen quenching activity of marine carotenoid fucoxanthin and its metabolites. J. Chem. Food Chem, 55 (21), 8516 - 8522.

Sugawara, T., Matsubara, K., Akagi, R., Mori, M., \& Hirata, T. (2006). Antiangiogenic activity of brown algae fucoxanthin and its deacetylated product, fucoxanthinol. J. Agri. Food Chem, 54, 9805-9810

Terasaki, M., Hirose, A., Narayan, B., Baba, Y., Kawagoe, C., Yasui, H., \& Miyashita, K. (2009). Evaluation of recoverable functional lipid components of several brown seaweeds (Phaeophyta) from Japan with special reference to fucoxanthin and fucosterol contents. $J$. of Phycol, 45(4), 974-980.

Torres, P. B., Chow, F., Furlan, C. M., Mandelli, F., Mercadante, A., \& Santos, D. Y. A. C. (2014). Standardization of a protocol to extract and analyze chlorophyll a and carotenoids in Gracilaria tenuistipitata Var. Liui. Zhang and Xia (Rhodophyta). Braz. J. Oceanogr, 62 (1), 57 - 63.

Xia, S., wang, K., wan, L., Li, A., Hu, Q., \& Zhang, C. (2013). Production, characterization, and antioxidant activity of fucoxanthin from the marine diatom Odontella aurita. Mar. Drugs, 11, 2667-2681

Zachary, I. (2003). Determination of Cell Number. In : Hughes, D. and H. Mehmet (Eds.). Cell Proliferation and Apoptosis. (pp. 368) BIOS Scientific Publisher Limited. 